\title{
Canada: over-pressurized
}

\author{
Fabio Magistris, MD (1) - Stefan Kojic, MD · Jennifer O'Brien, PhD • \\ Jonathan Gamble, MD
}

Received: 4 June 2018/Revised: 14 August 2018/Accepted: 19 September 2018/Published online: 17 October 2018

(C) Canadian Anesthesiologists' Society 2018

\section{To the Editor,}

In reference to the article published by Miao et al., ${ }^{1}$ we would like to provide further insight into the practices of cuff pressure manometry in the context of the Canadian Anesthesiologists' Society (CAS) guidelines. $^{2}$ Miao demonstrated that 33/113 (29\%) of endotracheal tube (ETT) cuffs and 8/14 (57\%) of supraglottic airway (SGA) cuffs exceeded the recommended maximum pressures of $30 \mathrm{cmH}_{2} \mathrm{O}$ and $60 \mathrm{cmH}_{2} \mathrm{O}$, respectively. ${ }^{3,4}$ Palpation of the pilot balloon was reported as the most common method to determine appropriate ETT cuff pressure. Fifty of 66 respondents (76\%) reported using cuff manometry less than once per month.

We conducted a two-part study: 1) a prospective evaluation of intraoperative ETT and SGA cuff pressures at four Saskatchewan hospitals, and 2) a Canada-wide survey of anesthesiologists' airway cuff management practices (see eAppendix, available as Electronic Supplementary Material). Research ethics board approval for both projects was obtained from the Regina Qu'Appelle Health Region and was exempted by the University of Saskatchewan Biomedical Research Ethics Board. Airway cuff pressures were measured in 101 patients aged $18 \mathrm{yr}$ or older between April 2017 and January 2018. The primary study outcome was median ETT and SGA cuff pressures

Electronic supplementary material The online version of this article (https://doi.org/10.1007/s12630-018-1236-6) contains supplementary material, which is available to authorized users.

F. Magistris, MD $(\bowtie) \cdot$ S. Kojic, MD · J. O'Brien, PhD .

J. Gamble, MD

Department of Anesthesiology, Perioperative Medicine and Pain

Management, University of Saskatchewan, Royal University

Hospital, Saskatoon, SK, Canada

e-mail: fabio.magistris@usask.ca using a cuff manometer (VBM Medizintechnik GmbH, Sulz, Germany). We designed a survey regarding cuff pressure monitoring practices according to standardized recommendations for survey development including pretesting, pilot testing, and clinical sensibility testing amongst anesthesia residents and staff anesthesiologists at our centre. The survey was then distributed to $1,661 \mathrm{CAS}$ members.

Results from our practice audit found that the median [interquartile range (IQR)] SGA cuff pressure was 110 [62120] $\mathrm{cmH}_{2} \mathrm{O}$, markedly above the recommended safe upper limit of $60 \mathrm{cmH}_{2} \mathrm{O}(P<0.001) .{ }^{4}$ The median $[\mathrm{IQR}]$ ETT cuff pressure was 48 [25-65] $\mathrm{cmH}_{2} \mathrm{O}$, also well above the recommended safe upper limit of $30 \mathrm{cmH}_{2} \mathrm{O}(P<0.001){ }^{3}$ ETT cuff pressures were within the proposed safe range $\left(20-30 \mathrm{cmH}_{2} \mathrm{O}\right)$ in only $7 / 60(12 \%)$ cases. ${ }^{3}$ Supraglottic airway cuff pressures were below the recommended maximum in $10 / 41(24 \%)$ cases, while $17 / 41(41 \%)$ had cuff pressures above the measurable limit $\left(120 \mathrm{cmH}_{2} \mathrm{O}\right){ }^{4}$

Our survey had a response rate of 215/1661 (13\%). Pilot balloon palpation was reported by 109 of 215 respondents $(51 \%)$ as the technique used to estimate cuff pressure, while 101/215 (47\%) reported using cuff manometry. This reported use may be an overestimate considering only $60 \%$ of centres had cuff manometers immediately available and only $24 \%$ and $42 \%$ of respondents could identify the recommended safe SGA and ETT cuff pressures (Table). ${ }^{3,4}$ Common reported barriers to cuff manometry use are the lack of availability, perceived lack of clinical evidence, and "laziness".

In summary, knowledge translation regarding the importance and implementation of airway cuff pressure management is limited. Airway cuff pressures in clinical practice often exceed recommended safe limits and are underestimated by anesthesiologists. Manometers should 
Table Responses to survey questions

\begin{tabular}{|c|c|c|c|c|c|}
\hline Cuff measurement technique $(n=215)$ & $\begin{array}{l}\text { Palpation } \\
51 \%(109)\end{array}$ & $\begin{array}{l}\text { Manometry } 47 \% \\
\quad(101)\end{array}$ & $\begin{array}{l}\text { MLT } \\
24 \%(52)\end{array}$ & $\begin{array}{l}\text { MOV } \\
22 \%(47)\end{array}$ & $\begin{array}{l}\text { None } \\
16 \%(35)\end{array}$ \\
\hline $\begin{array}{l}\text { Who inflates cuff } \\
(n=215)\end{array}$ & $\begin{array}{l}\text { Anesthesiologist } 80 \% \\
\quad(173)\end{array}$ & $\begin{array}{l}\text { Nurse } \\
44 \%(95)\end{array}$ & $\begin{array}{l}\text { Anesthesia } \\
\text { assistant } \\
29 \%(61)\end{array}$ & $\begin{array}{l}\text { Other } \\
7 \%(16)\end{array}$ & \\
\hline $\begin{array}{l}\text { Frequency of manometer use with ETT } \\
(n=211)\end{array}$ & $\begin{array}{l}\text { Not used } \\
78(37 \%)\end{array}$ & $\begin{array}{l}1-25 \% \text { of cases } \\
50(24 \%)\end{array}$ & $\begin{array}{l}26-50 \% \text { of } \\
\text { cases } \\
7(3 \%)\end{array}$ & $\begin{array}{l}51-75 \% \text { of cases } \\
0(0 \%)\end{array}$ & $\begin{array}{l}76-100 \% \text { of } \\
\quad \text { cases } \\
61(29 \%)\end{array}$ \\
\hline $\begin{array}{l}\text { Frequency of manometer use with SGA } \\
(n=210)\end{array}$ & $\begin{array}{l}\text { Not used } \\
123(59 \%)\end{array}$ & $\begin{array}{l}1-25 \% \text { of cases } \\
31(15 \%)\end{array}$ & $\begin{array}{l}26-50 \% \text { of } \\
\quad \text { cases } \\
9(4 \%)\end{array}$ & $\begin{array}{l}51-75 \% \text { of cases } \\
6(3 \%)\end{array}$ & $\begin{array}{l}76-100 \% \text { of } \\
\quad \text { cases } \\
41(20 \%)\end{array}$ \\
\hline $\begin{array}{l}\text { Cuff manometers "immediately available"? } \\
(n=210)\end{array}$ & $\begin{array}{l}\text { No } \\
82(39 \%)\end{array}$ & $\begin{array}{l}\text { Yes } \\
128(61 \%)\end{array}$ & & & \\
\hline $\begin{array}{l}\text { Recommended maximum ETT cuff pressure } \\
(n=204)\end{array}$ & $\begin{array}{l}\text { Unsure } \\
58(28 \%)\end{array}$ & $\begin{array}{l}10 \mathrm{cmH}_{2} \mathrm{O} \\
22(11 \%)\end{array}$ & $\begin{array}{l}20 \mathrm{cmH}_{2} \mathrm{O} \\
83(41 \%)\end{array}$ & $\begin{array}{l}30 \mathrm{cmH}_{2} \mathrm{O} 90 \\
\quad(44 \%)\end{array}$ & $\begin{array}{l}40 \mathrm{cmH}_{2} \mathrm{O} \\
9(4 \%)\end{array}$ \\
\hline $\begin{array}{l}\text { Recommended maximum LMA } 4 \text { classic cuff } \\
\text { pressure } \\
(n=203)\end{array}$ & $\begin{array}{l}20 \mathrm{cmH}_{2} \mathrm{O} \\
52(26 \%)\end{array}$ & $\begin{array}{l}40 \mathrm{cmH}_{2} \mathrm{O} \\
37(18 \%)\end{array}$ & $\begin{array}{l}60 \mathrm{cmH}_{2} \mathrm{O} \\
52(26 \%)\end{array}$ & $\begin{array}{l}80 \mathrm{cmH}_{2} \mathrm{O} \\
0(0 \%)\end{array}$ & \\
\hline
\end{tabular}

* Responses are in \% (n); participants may have selected more than one response; thus, percentages do not sum across responses to $100 \%$. ETT $=$ endotracheal tube; LMA = laryngeal mask airway; MLT = minimal leak technique; MOV = minimal occlusive volume; SGA = supraglottic airway

be used routinely as cuff pressures inflated using other methods are typically outside the recommended range. Our study adds to Miao's results by demonstrating that current clinical practice does not meet current guidelines and potentially exposes patients to harm. ${ }^{3-5}$ Our study offers some insight into the barriers to the regular use of cuff manometry, notably a common lack of availability.

Acknowledgements The researchers gratefully acknowledge the assistance of the Saskatoon Health Region and the Regina Qu'Appelle Health Region. We also acknowledge the support of Dr. David Campbell and Dr. Theo LeRoux as the anesthesiology department heads in Saskatoon and Regina.

Conflict of interest Commercial or non-commercial affiliations that are or may be perceived to be a conflict of interest with the work for each author; and any other associations, such as consultancies: No author has any commercial or other affiliations that are, or may be perceived to be, a conflict of interest.

Editorial responsibility This submission was handled by Dr. Gregory L. Bryson, Deputy Editor-in-Chief, Canadian Journal of Anesthesia.

Funding sources Funding provided by the Department of Anesthesiology, Perioperative Medicine and Pain Management at the University of Saskatchewan for survey distribution to Canadian Anesthesiologists' Society members.

\section{References}

1. Miao I, Jee R, Pysyk CL. Under pressure: an audit of airway device pressures. Can J Anesth 2018; 65: 726-7.

2. Dobson G, Chong M, Chow L, et al. Guidelines to the Practice of Anesthesia - Revised Edition 2018. Can J Anesth 2018; 65: 76104.

3. Seegobin RD, van Hasselt GL. Endotracheal cuff pressure and tracheal mucosal blood flow: endoscopic study of effects of four large volume cuffs. Br Med J (Clin Res Ed) 1984; 288: 965-8.

4. Seet E, Yousaf F, Gupta S, Subramanyam R, Wong DT, Chung F. Use of manometry for laryngeal mask airway reduces postoperative pharyngolaryngeal adverse events: a prospective, randomized trial. Anesthesiology 2010; 112: 652-7.

5. Sultan P, Carvalho B, Rose BO, Cregg R. Endotracheal tube cuff pressure monitoring: a review of the evidence. J Perioper Pract 2011; 21: 379-86. 